\title{
Making a Count of Hagiographic Books. Quantitative Aspects of the Production and Dissemination of Latin Hagiographic Literature $\left(2^{\text {nd }}-15^{\text {th }}\right.$ Centuries)
}

Guy Philipparts's desire to create a vast database of hagiographic volumes lies at the root of the present research, which can be set within the wider framework of an initiative aimed at renewing the history of hagiographic literature. Philipparts's project is centred on Hagiographies, an international history of hagiographic literature which thus far numbers three volumes. Our focus of interest tempted us to combine Latin hagiographic literature with the history of the book. ${ }^{1}$ The cultural, social and religious foundations of the history of the dissemination and reception of the saints' legends made it impossible for us to evade some fundamental questions that can only be addressed by means of a numerical evaluation: which legends were most read and why; what were the freedoms and constraints experienced by the editors of the Lives of the Saints; and when did hagiography as a genre begin to wane? Many other questions have since been added to this list.

\section{The Légendiers Latins database}

In 1994, a project for the creation of a database of manuscript hagiographies was launched by Guy Philippart. Subsequently, the project has gradually been enriched by the participation of several co-contributors. Part of the database which has already been published (in collaboration with the Société des Bollandistes) can be consulted online. The database was originally conceived of both as a means to study the dissemination of Latin hagiographies and as a heuristic tool to spare researchers the need to carry out time-consuming counts

Translated from the French into English by Mark Livesey. Original published as Trigalet, Michel (2001), 'Compter les livres hagiographiques. Aspects quantitatifs de la création et de la diffusion de la littérature hagiographique latine (II - XV siècle)', in Gazette du livre médiéval, 38: 1-13.

1 Philppart 1996.

Ә Open Access. (C) 2022 Michel Trigalet, published by De Gruyter. (c) BY-NC-ND This work is licensed under the Creative Commons Attribution-NonCommercial-NoDerivatives 4.0 International License. https://doi.org/10.1515/9783110743838-004 
in about forty manuscript catalogues. The heuristic aspect, which has raised a number of problems, has previously been addressed in an article that was published in Le Médiéviste et l'ordinateur. ${ }^{2}$

The Bollandists described approximately 4,500 Latin hagiographical manuscripts in their specialised catalogues. ${ }^{3}$ Frankly speaking, from a purely opportunistic standpoint the prospect of extracting something useful from this windfall was rather attractive-technical challenges notwithstanding. The Bollandists' descriptions were encoded in (more or less) full form, which entailed the provisional encoding of some 48,700 examples of manuscripts bearing hagiographic texts.

It was not difficult to foresee that this sample would prove inadequate, not simply because of its size, but for far more fundamental reasons. The first steps taken by the Bollandists towards a census of hagiographic manuscripts were totally lacking any a priori scientific foundation. We therefore set out to assemble our sample by adopting a dual approach: first, by adding to it hagiographic manuscripts originating from regions of Europe that had been scarcely (or not at all) explored by the Bollandists; second, by creating a systematic inventory of all surviving hagiographic manuscripts, and therefore including all those whose descriptions had not been not published by the Bollandists. However, several hundred uncatalogued funds have yet to be scrutinised, a process that would necessitate engaging two or three full-time researchers for several years. Consequently, this 'ideal' census had to be curtailed and was ultimately limited to 7,463 manuscripts, hence about three quarters of the total number of items described in detail.

\section{The hagiographic 'genre'}

For the description of manuscripts, consultation of the Bibliotheca Hagiographica Latina and its Novum Supplementum (from now on we shall refer to this source by its customary acronym: $B H L),{ }^{4}$ which collects data on the ensemble of devotional texts that narrate the Lives of the Saints, is utterly indispensable. Moreover, this repertory offers the enormous advantage of making it easier to manage electronic data by identifying each text by means of a numerical code.

2 De Vriendt / Trigalet 1996-1997.

3 Bibliotheca Hagiographica Latina manuscripta 1998. http://bhlms.fltr.ucl.ac.be (last access 08/03/2020).

4 Bibliotheca hagiographica latina 1898-1901; Fros 1986. 
The question concerning genre is not without importance. The gathering together in the $B H L$ of texts which at first glance appear rather disparate, consisting of biographies, passion manuscripts, relic histories and miracle collections, in actual fact fully reflects a medieval reality that legendaries bear tangible witness to. Looking beyond formal or documentary differences, the specific milieu that commissioned and appreciated this form of literature, and those who manufactured and disseminated it, belong to practically the entire range of genres comprising medieval literature. One sees authors at the forefront of humanism mingling with monks who rather uncouthly defend their material interests. Mere compilers are found in the same echelon as the most creative and innovative writers. A few well-paid professionals who accepted commissions from aristocratic clients probably represent an exception among the majority of occasional, non-professional writers.

The poet Henri d'Avranches (who died in 1260) represents an untypical example: he was paid to write by a pope, two emperors, three kings and six archbishops, in addition to twelve bishops and numerous other ecclesiastical dignitaries and laymen across Europe. Among his commissioned works we find some Lives of Saints; these were disseminated as manuscripts in very small numbers which bore no relation to their literary merit.

Hagiographic works that occupy an entire volume on their own are quite rare. The most favoured vehicle for hagiographies, though not the only one, is a form of literary anthology-the so-called 'legendary'. Most of the time, the texts are arranged in an order based on the calendar. Sometimes, though not always, they were divided into lessons at the time of the project's conception, or alternatively at a later date. In addition to well-documented readings at religious services, refectory readings were also made, as well as private readings or study sessions aimed at bolstering sermons and meditation, or simply to satisfy an interest in history.

Different types of manuscript correspond to different uses. The size, number of units, and sometimes non-hagiographic context are all elements which play a clear role within the setting of a history of the spread of culture. We have endeavoured to highlight these aspects within the framework of our thesis. Here, we shall not be furnishing any definitive results; instead, we have chosen to focus on some key methodological issues. 


\section{Information collected in the Légendiers Latins database}

Accordingly, we shall start out by providing a brief overview of the information contained in the database. We will distinguish between data on the 'saints', data on the texts, and data on the manuscripts. For the first two categories, the $B H L$ represents a practically exhaustive repertory.

When we speak of 'saints', we are not referring to all the figures that the Church developed a cult around. Instead, we are limiting ourselves to those for whom Latin biographies were written before the year 1500. We have treated these figures as 'heroes on paper', so to speak. Above all, it is the legend that has attracted our interest; only secondarily does the historical figure emerge more or less clearly as a sort of 'by-product'. We have therefore chosen to employ the expression 'literary dossiers' (a concept that should be interpreted in its broadest sense as a collection of narrative texts dedicated to a saint or a group of saints, or figures recognised as such), rather than 'saints'. The Latin dossiers total 3,318, if one excludes duplicates. The saints are described according to their basic typology, geographical origin and date, based on information gleaned from literary sources, which can vary considerably depending on the tradition concerned.

In addition, basic information on the 13,600 Latin texts that are currently known and on their authors is collected. Essentially, such information includes the level of certainty vis-à-vis the attribution of a text, the date and place of its composition, and its end-user. However, for the majority of texts it is not possible to collect any information that is in the least bit reliable.

The relative paucity of descriptions dating from the beginning of the $20^{\text {th }}$ century, which represented the culmination of the Bollandists' cataloguing activity, impeded us from gathering more detailed information of a codicological nature. We have therefore considered the following (readily available, on the whole) details: support type, size, number of leaves, dating, presence or absence of a colophon, mention of date, copyists, and historical owners. Wherever it proved possible to identify codicological components, we have done so. In most cases, we applied the concept of 'editorial sections' in order to indicate clear changes in datings within a codex which cannot be attributed to a change in 'codicological section', nor to a simple change of scribe's hand. Our aim was to make it possible to assign datings to groups of witnesses of hagiographic texts. 
The manuscript witnesses of works are distinguished through their foliation, which can be identified by the presence within a manuscript of a discontinuity, usually marked by a table of contents. Each witness is identified by one or more $B H L$ codes, in accordance with established practice.

\section{Methodological challenges specific to the hagiographic book}

\subsection{Loss of hagiographic patrimony}

Research on liturgical manuscripts has revealed a very high loss rate. Hagiographic manuscripts, despite their liturgical use, should not be considered equivalent. Their historical dimension and their role in identity construction account for their being spared many vicissitudes over the course of time. All the same, we still cannot confirm that, more than other types of manuscript, they were carefully preserved, although there is a good possibility that they were.

In a genre where rewriting was a very widespread practice, periodic updating could explain the disappearance of large numbers of books, especially those which hosted ancient texts. We can only second the opinion of Joseph-Claude Poulin (formed after twenty years of research carried out within the framework of the SGH - Sources Hagiographiques de la Gaule project and based on the list of manuscripts identified), when he says:

Today, about half the manuscripts are found in Paris; the remainder are dispersed throughout France and Europe, particularly in Italy and Great Britain. In light of the information acquired up till now, it can be confirmed that the ancient texts are usually best preserved in regions quite distant from the places where worship actively took place. ${ }^{5}$

This consistent finding can be supplemented by another: a certain number of hagiographic texts were scarcely circulated outside their region of origin. Whenever one scrutinises funds of a markedly local character, one is virtually guaranteed to discover some rare texts. This provides a measure of their 'fragility'. The loss of a local collection can simultaneously result in the disappearance of a unique textual patrimony. However, these peripheral phenomena only have a very small effect on the overriding production trends.

5 Poulin 1996. 


\subsection{Counting units: collections, editorial sections, witnesses}

Most specimens are concentrated in specialised books-traditional legendaries, abridged legendaries, martyrologues, and libelli dedicated to particular saints. The remainder serve as a vehicle for a rather mixed bag: a body of works by a single author, liturgical manuscripts, collected letters, encyclopaedias, and Bibles. Pure chance, or the opportunity presenting itself to complete a quire or to place a note in a margin or on a flyleaf undoubtedly provide the explanation for the large number of unusual bedfellows.

Hagiographic collections have been the subject of in-depth analyses ever since the works of the Bollandist Albert Poncelet first appeared. Their quantitative studies raise many questions. The first conundrum to address is how to distinguish collections from each another with sufficient accuracy. In fact, today it can be the case that such collections have been broken up and scattered among several different libraries. Non-specialists will not always be particularly concerned about investigating the completeness of a collection of legends when they are compiling a catalogue of manuscripts, given the considerable difficulty presented by such a task. This would require expert knowledge of each item, and almost always a direct examination of the different parts of a collection. Even when this is possible, there is no guarantee that a researcher will be able to locate missing items, assuming they still exist.

In addition, the complementariness of collections can be positioned parallel with the overall corpus of legends that was at the disposal of a religious institution. Thus, a traditional passionary could be completed by a collection of lives of confessors of local origin. Signs of complementariness can be found in certain manuscripts, thanks to the instructions for their use left by scribes. For example, in the Bodleian Library's Latin manuscript 285 ( $13^{\text {th }}$ century), inscribed on f. $165 \mathrm{v}$ we find: Perlectis itaque passionalibus, legatur Vita sancti Martialis episcopi. Queratur in armario, in veteri libro spisso et paruo qui intitulatur 'Diadema monachorum'. The opposite phenomenon, namely the formation of factitious collections, is equally difficult to detect.

The reconstruction of an ancient book collection requires the expertise of an accomplished researcher even to tackle a single case. It is quite simply impossible to process several thousand cases in a database, unless one resorts to using artificial intelligence. Such an undertaking may soon be possible for historians with appropriate IT skills. In the meantime, we have come up against a temporary 'roadblock' as far as questions on the typology of manuscripts and completeness of collections are concerned. During the initial examination, all manuscripts containing hagiographic texts will be considered hagiographic. Therefore, any conclusions based on 
the rough count of manuscripts must be viewed with a degree of caution. Accordingly, we shall by preference concentrate on the number of text witnesses.

What has been stated above is true of collections said to be 'traditional', which reached their zenith in the $12^{\text {th }}$ and $13^{\text {th }}$ centuries. These contrast with collections of abridged legends-known from the Middle Ages as legendae novae-which appeared towards the end of the $12^{\text {th }}$ century and enjoyed huge popularity, almost entirely due to the Golden Legend. This is borne witness to by about a thousand surviving witnesses, representing about two centuries of their dissemination in manuscript form. The corpus of texts found in these can vary quite a lot from one manuscript to another and, even if most of the time one can identify a common nucleus, many collections were completed by adding other legends so as to adapt them to local needs. On the whole, one can quite easily verify the completeness of collections of the Golden Legend type; indeed, they are generally contained within a single volume.

The difficulty, however, lies elsewhere. The Golden Legend volumes are never described in detail. Omitted chapters are rarely mentioned, and appended legends owe their description to their rarity or to the unusualness of their presence in the collection. This consistent finding applies to all the Bollandist catalogues, as well as to many others. Now, it is impossible to overlook the role played by the Golden Legend in the dissemination of a legend.

By attributing to each abridged collection an average number of witnesses of works, estimated on the basis of surviving copies and a few described manuscripts, some rough calculations on the number of examples can be applied to the entire corpus of works contained within the database, with an acceptable margin of error. Meanwhile, we must wait until the complete descriptions of the 275 Golden Legends in the corpus have been put together, either on the basis of data contained in Barbara Fleith's catalogue, ${ }^{6}$ or through a direct examination of the relevant manuscripts.

\subsection{The hagiographic text: description and dating}

We have the good fortune to possess a highly detailed census of Latin hagiographic texts, but the 13,600 identification numbers contained in the BHL do not all convey the same meaning. A number might be allocated to a recension, which is sometimes represented by a sole manuscript, a part of a recension, in the case of works divided into multiple volumes, or even to a miracle text contained within a miscellany, whilst in similar cases, a collection of miracle texts can be identified by a single

6 Fleith 1991. 
number. A simple variant of an incipit may, in certain intricate manuscripts, justify the creation of an identification number. Finally, several thousand abridged texts, often resembling the records of historical martyrologues, but sometimes in the form of more fully developed writing, are entirely bereft of numbers.

Take the Golden Legend. The work as a whole is given the number BHL 9035. However, 110 chapters are not allocated with their own numbers, despite the fact that they appear in the catalogue. The remaining 54 chapters all have individual numbers; for example, the abridgement of the Life of Saint Dominic (BHL 3130). In the $B H L$ catalogue, this issue has been dealt with in a practical way. In the manuscripts, what is called the Legenda aurea, or which resembles the same, leaves us faced with about a thousand more or less different collections.

In order to factor in this diversity, we came up with the somewhat vague concept of a 'textual unit' to describe the particular object allocated with a BHL number. Should one forgo counting these? Because of the sheer number of texts, one might naturally be concerned that inconsistencies may have been generated over and over again. Now, if one takes a step back and examines the matter from a greater distance, it is largely speaking the homogeneity of the process that prevails when determining the numbers that are allocated. A number generally equates to an apparently complete work (rather than to part of a larger one), which is simultaneously an autonomous one (circulated in different types of manuscript).

As a result, it becomes possible to offer a statistical insight into several of the phenomena linked to the creation of a literary work, rather than solely to its production in manuscript form. Accordingly, in an article published in the proceedings of the Medieval Latin symposium held in Cambridge in 1998, we attempted to shed some light on the trends observed in the creation of Latin hagiographies dating from the $15^{\text {th }}$ century. ${ }^{7}$ In order to accomplish this, we did not utilise the entire corpus, which would represent an excessive quantity of data to process, but instead used (provisionally) two samples each composed of two hundred texts drawn at random from the total of 13,600 . The present results still do not provide the degree of certitude one might hope for. To achieve an acceptable margin of error, one would have to analyse a sample composed of at least a thousand texts, a task that would obviously entail a great deal of work. With only 400 texts, there is a considerable risk that the small differences between time periods will be insignificant.

7 Philippart / Trigalet 2002. 


\subsection{Old saints, new saints, duration of textual tradition}

In hagiography, as in other genres, although perhaps more so than in other genres, accumulation phenomena may have played a role in several ways. The more time passes, the more the number of potential protagonists of hagiographic texts increases. Even allowing for the fact that some saints fall into relative obscurity, it has to be admitted that the most ancient saints and martyrs enjoy an advantage. The compilers insisted on a wider (and certainly earlier) dissemination of such texts. Consequently, the relative success of a manuscript can only be expressed in relation to the total number of 'available' saints at a given moment in time.

The dossiers known for a long time and which enjoyed wide dissemination may have satisfied the need for hagiographic books. Fresh demand may have been partly fulfilled by the second-hand market, through exchanges, or simply by the continuing use of old books. Accordingly, any interpretation of a legend's success must factor in the duration of its dissemination. Given that it is generally unknown when a legend first started to be disseminated, the date of a given saint's death provides us with a handy terminus ante quem non.

When the Lives of Saint Francis arrived on the hagiographic book 'market', they might have been copied separately or added to a new collection. The Life of Saint Martin was known and disseminated for eight centuries. By the $13^{\text {th }}$ century it was no longer the only hagiographic text on Martin-indeed, far from it. In addition, about $90 \%$ of the dossiers were already known, and the biographies relating to these were copied for a period stretching from the $2^{\text {nd }}$ century to the third decade of $13^{\text {th }}$ century. A part of these dossiers would subsequently accompany each copy of a Life of Saint Francis within the overall framework of a general legendary (this occurs in about one case in five, for biographies of Saint Martin), thereby continuing to increase their significance in absolute numbers.

\section{Production trends of the hagiographic book}

The sample of manuscripts that we based our research on includes 5,050 items selected from the 7,463 manuscripts which constitute the Légendiers latins database, their current place of preservation being the main selective criterion. The different trends evidenced by the book production curve are striking when one compares the funds originating from Northern France (1,034 mss), Western Germany (318 mss), and Northern Italy ( $644 \mathrm{mss})$. The funds compared are individuated based on the location where they are currently held. Sources of perturbation were kept at bay by injecting exogenous manuscripts, such as those originating from Vatican funds in the case of 
Italy, and those from the Bibliothèque nationale in the case of France. Our ideal was to build samples related to the manuscripts' places of production, but so far this has proved impossible because the data are too fragmentary (Chart 1).

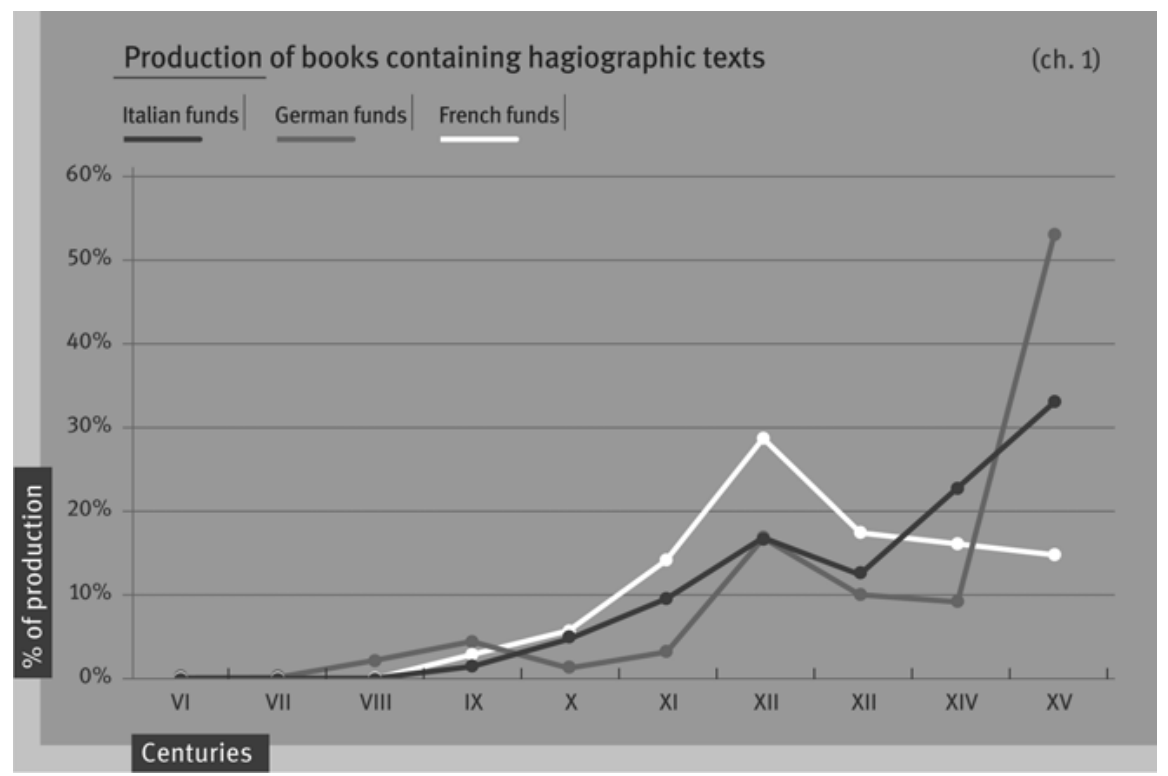

Chart 1: Production of books containing hagiographic texts

The 'German' growth in the $15^{\text {th }}$ century is entirely characteristic of the concentration of production within the Empire, including, albeit to a lesser extent, in the provinces that constitute present day Belgium. French growth appears to draw to a halt in the $13^{\text {th }}$ century, and then stagnates for the rest of the period. This reduction would have been less noticeable if the manuscripts of the Bibliothèque nationale had been taken into account, given the large number of copies of the Golden Legends it holds. Once again, this finding is scarcely different to what was observed in book production taken as a whole. Northern Italy is the only region in Europe which saw an increase in hagiographic book production in the $14^{\text {th }}$ century. A number of successful compilers originated from late $13^{\text {th }}$ - or early $14^{\text {th }}$-century Italy, among whom we find Jacob of Voragine and Bartholomew of Trent. Upstream, in the $13^{\text {th }}$ and $14^{\text {th }}$ centuries, Italy was the geographical area in Europe that spawned the highest number of saints, some of whom were canonised.

Presented in this way, these trends do not make it possible for us to distinguish between what is peculiar to hagiographic book production and what one observes in 
book production trends in general. Furthermore, we have placed an emphasis on the caution one must exercise vis-à-vis calculations based on the number of sections. By using witnesses as counting units, the results appear rather more meaningful (Chart2).

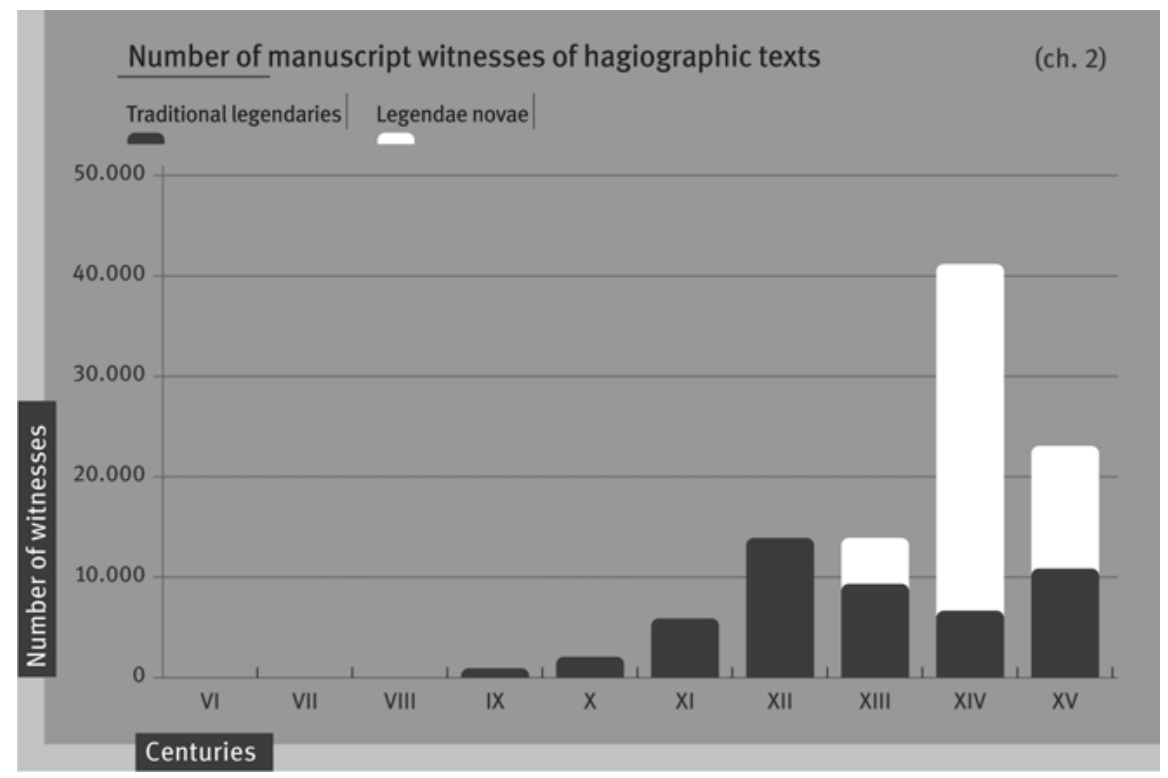

Chart 2: Number of manuscripts containing hagiographic texts

The copying of manuscripts faltered during the $13^{\text {th }}$ century, a period that coincides with the apogee of the compilation of traditional collections. Such collections were very expensive to produce because they consumed large amounts of parchment and sometimes comprised several volumes.

The increase in the number of manuscript witnesses betrays an interest in them in the Late Middles Ages in particular; this phenomenon is well documented, thanks to the prologues written by the authors of abridged legendaries (see the recent study by François Dolbeau on this subject). ${ }^{8}$ The Golden Legend, together with any potential supplements attuned to the sanctoral cycle specific to a particular diocese, was quickly able to satisfy (in a cost-effective way) the new needs generated by the appearance of a fresh audience, and the necessity

8 Dolbeau 2000. 
to replace ageing collections and those which had deteriorated as a result of being used for too long.

For the $15^{\text {th }}$ century, we shall concern ourselves with an output which only affected a little more than half of it. It is difficult to gauge the precise impact that printing had on manuscript production. Indeed, one cannot simply add the number of early printed books to the figures collected for manuscript production. Therefore, the decrease that occurred in the $15^{\text {th }}$ century is perhaps not an entirely real one when viewed in relation to the $14^{\text {th }}$ century. The decrease only becomes evident when one considers other factors, such as the overall production of all genres combined. One solution could be to examine intervals composed of half a century or less.

Here, we are tempted to see the effect of several factors which may have resulted in a reduction of interest in Latin hagiographic literature commencing in the $13^{\text {th }}$ century:

1. The movement towards centralisation and unification of the liturgy and the way in which the veneration of saints was recognised-canonisation in particular. This reduced the total number of saints and, more than anything, focused attention on a small number of them.

2. The diversification of areas of interest and fields of knowledge must have had the effect of weakening a literature that struggled to renew itself.

3. The traditional clerical readers of hagiography gradually turned away from a genre thenceforth considered utilitarian. Preaching and providing religious instruction to parishioners were given priority by the compilers of abridged legendaries. In the long run, the vulgarisation of the genre eroded its success in the sphere of literature.

4. The changes that occurred in dissemination methods-which is to say the standardisation of sanctorals and the abbreviation of texts-acted to reduce the size and number of pages in hagiographical books and, as a result, the total number of books, whilst at the same time maintaining sufficient access to essential information. Consequently, a void was created which those of an encyclopaedic mind took advantage of by assembling the largest possible number of saints (Petrus Calò, Petrus Natali, Johannes Gielemans, Boninus Mombritius) in learned and documentary manuscript summae of rather restricted dissemination. 


\section{Strengths and weaknesses of a quantitative study}

We shall conclude this brief overview by underscoring some of the more glaring omissions of quantitative studies in the sphere of book history. We should mention, above all, the difficulty experienced in comparing results. The majority of research projects have been carried out in an isolated way and even if their starting points have often been identical (i.e. a corpus of undated and dated manuscripts) they have produced rather different results that are sometimes incompatible.

Here, we shall examine a specific example to illustrate our point. Currently, it is impossible to compare the production figures of one region with those of another, because one can only examine trends rather than analyse absolute values. It would be rather rash to put forward any estimates of manuscript loss rates based in part on the rates observed in the world of the incunabula. Such an approach, proposed by Uwe Neddermeyer, ${ }^{9}$ led to an estimate of 1.1 million manuscripts produced in the Empire during the $15^{\text {th }}$ century, based on 75,000 surviving specimens. Even more problematic are the loss rates inferred from the previous centuries, for which we have no reference points.

Without entering into this thorny debate, here we will simply point out that absolute values would provide the advantage of making it possible to compare the production rates for different genres, without having to examine the overall production of all the genres combined. One could certainly profit from taking a closer look at methodological matters. However, the most important issue remains the correct cataloguing of the numerous funds which are still inaccessible to researchers up to the present day.

Should the reader now wish to compare these conclusions and extrapolations with those advanced by previous studies carried out on the same subject, he/she would certainly notice that many of them had already been stated before the present research programme was set forth. The examination of many legendaries and the scrutiny of numerous hagiographic manuscripts produced results and prompted hypotheses which were, in large part, confirmed by our work. Non-quantitative explanatory models of the production and dissemination of hagiography are not something entirely new, and therefore it is only to be expected that our count should in part match others. Researchers familiar with these issues will therefore not be altogether surprised to discover that, for example, the legendae novae played

9 Neddermeyer 1998. 
an important role in the wider dissemination of the Lives of the Saints in the Late Middle Ages. Nevertheless, here we consider it important to underscore three points: the highlighting of the range of phenomena-even in the absence of absolute values-and, above and beyond differences and similarities in relation to what was 'expected', the formulation of new questions and the shedding of light on unexpected phenomena, even if of these there are only a few.

\section{References}

Bibliotheca Hagiographica Latina antiquae et mediae aetatis (1898-1901), 2 vols, Bruxelles: Société des Bollandistes -latest supplement: Fros 1986.

Bibliotheca Hagiographica Latina manuscripta. Index analytique des Catalogues de manuscrits hagiographiques latins publiés par les Bollandistes (BHLMs) (1998), http://bhlms.fltr.ucl.ac.be/.

De Vriendt, François/ Trigalet, Michel (1996-1997), 'Littérature hagiographique et bases de données. À propos de deux projets en cours à l'Université de Namur', in Le médiéviste et l'ordinateur, 34: 5-16.

Dolbeau, François (2000), 'Les prologues des légendiers latins', in Hamesse, Jacqueline (ed.), Les prologues médiévaux, Turnhout: Brepols (Textes et Etudes du Moyen Âge, 15), 345393.

Fleith, Barbara (1991), Studien zur Überlieferungsgeschichte der lateinischen Legenda Aurea, Bruxelles: Société des Bollandistes (Subsidia hagiographica, 72).

Fros, Henryk (1986), Bibliotheca Hagiographica Latina antiquae et mediae aetatis. Novum supplementum, Bruxelles: Société des Bollandistes (Subsidia hagiographica, 70).

Neddermeyer, Uwe (1998), Von der Handschrift zum gedruckten Buch. Schriftlichkeit und Leseinteresse im Mittelalter und in der frühen Neuzeit; quantitative und qualitative Aspekte, Wiesbaden: Harrassowitz (Buchwissenschaftliche Beiträge aus dem Deutschen Bucharchiv München, 61).

Philippart, Guy (1996), 'Pour une histoire générale, problématique et sérielle de la littérature et de l'édition hagiographiques latines de l'Antiquité et du Moyen Âge', in Cassiodorus, 2: 197-213.

Philippart, Guy / Trigalet, Michel (2002), 'L'hagiographie latine du XI' siècle dans la longue durée. Données statistiques sur la production littéraire et l'édition médiévales', in Herren, Michael W. / MacDonough, Christopher James / Arthur, Ross G. (eds), Latin Culture in the Eleventh Century: Proceedings of the Third International Conference on Medieval Latin Studies, Cambridge, September 9-12, 1998, 1-2, Turnhout: Brepols.

Poulin, Joseph-Claude (1996), 'Le projet de recherche sur les sources hagiographiques de la Gaule antérieures à l'an Mil (SHG)', in Scriptorium, 50: 196-197. 